\title{
Biology and Management of Spanish Needles (Bidens spp.) in Ornamental Crop Production ${ }^{1}$
}

\author{
Yuvraj Khamare, Chris Marble, Shawn Steed, and Nathan Boyd ${ }^{2}$
}

\section{Introduction}

All eight species of Bidens in Florida are commonly referred to as Spanish needles or beggar-ticks (Wunderlin, 2019). This document focuses on Bidens alba and B. pilosa, which are common weeds in container nurseries and landscapes in Florida. Both of these species are very similar in appearance and biology and are capable of interbreeding (Norton, 1991). Due to the similarity between these species, they are sometimes recognized as one in the literature (Wunderlin, 2019). Their differences are distinctive, however, as B. pilosa flowers usually do not have petals while $B$. alba usually does. $B$. alba is also more widely distributed throughout Florida than B. pilosa. For the purposes of this document, we refer to both species as "Spanish needles." This EDIS publication is designed for landowners, gardeners, horticulturalists, and consumers hoping to learn more about Spanish needle classification and management.

\section{Species Description}

\section{Class}

Dicotyledonous plant

\section{Family}

Asteraceae (Compositae)

\section{Other Common Names}

Blackjack, beggar-ticks, cobbler's pegs, farmer's friends

\section{Life Span}

Both species are annual or short-lived perennials

\section{Habitat}

Spanish needles occur in many different habitats, ranging from moist fertile soil to dry and infertile soil and sandy soils. They are most often found in moderately dry, full-sun areas that have been disturbed by human or animal activity. Spanish needles are also known to grow in grasslands or pastures, forest clearings, wetlands, roadsides, ditch banks, landscapes, and agricultural production areas such as nurseries. In landscapes, these weeds can grow in planting beds or in turf, while in nurseries they are most often observed in non-crop areas and in pot drain holes. Spanish needles may also be found growing in the potting media of container-grown ornamentals, especially crops that are in production for a long period of time.

1. This document is ENH1308, one of a series of the Environmental Horticulture Department, UF/IFAS Extension. Original publication date April 2019. Visit the EDIS website at https://edis.ifas.ufl.edu for the currently supported version of this publication.

2. Yuvraj Khamare, graduate research assistant; Chris Marble, assistant professor, Environmental Horticulture Department, UF/IFAS Mid-Florida Research and Education Center; Shawn Steed, associate professor, Horticultural Sciences Department, UF/IFAS Gulf Coast REC; and Nathan Boyd, multi-county environmental horticultural Extension agent III, UF/IFAS Extension Hillsborough County; UF/IFAS Extension, Gainesville, FL 32611.

The use of trade names in this publication is solely for the purpose of providing specific information. UF/IFAS does not guarantee or warranty the products named, and references to them in this publication do not signify our approval to the exclusion of other products of suitable composition. All chemicals should be used in accordance with directions on the manufacturer's label. 


\section{Distribution}

Bidens alba is native to Florida but can also be found in other tropical and subtropical regions in the Americas (USDA-NRCS, 2019). Bidens pilosa is considered native to Central and South America and was introduced into North America (USDA-NRCS, 2019; Wunderlin, 2019). Both species have become weeds in parts of Europe, Asia, Africa, and the Pacific Islands. They can generally be found growing throughout the year in tropical regions but grow most vigorously during warm weather and when rainfall is abundant.

\section{Growth Habit}

Both species are upright annual to perennial herbs growing up to 36 inches in height (Figure 1). Established plants may develop a somewhat woody stem with age. These species will often colonize an area quickly via seed production.

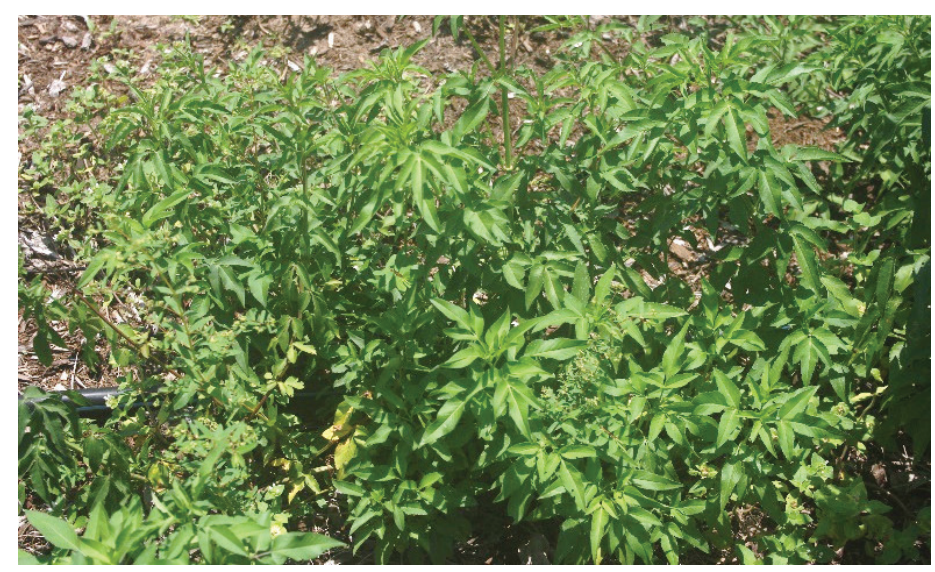

Figure 1. Bidens alba plant.

Credits: Annette Chandler, UF/IFAS

\section{Seedling}

Seedlings have strap-shaped cotyledons around 0.5 to 1 inch long with green to purplish hypocotyls, or stems of a germinating seedling. The first emerging true leaves are similar to mature leaves.

\section{Shoot}

The stems of both species are angled, smooth or lightly hairy, and green to purplish in color (Figure 3). Leaves are dark green and oppositely arranged on stem with leaf stalks 0.5 to 3 inches long. Leaf margins have forward-pointed teeth. The lower leaves are simple, egg-shaped, and serrate, while the upper leaves compound with 2-3 pairs of pinnae and a single terminal leaflet (Figure 4).

\section{Roots}

Spanish needles have deep taproot systems that may be extensive depending on plant size and age.

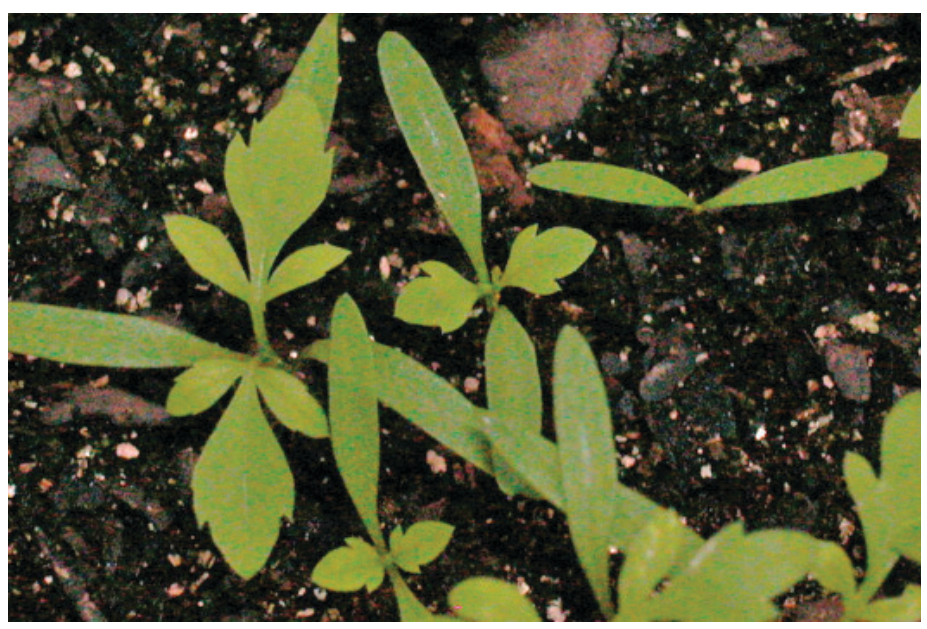

Figure 2. Bidens alba seedlings.

Credits: Annette Chandler, UF/IFAS

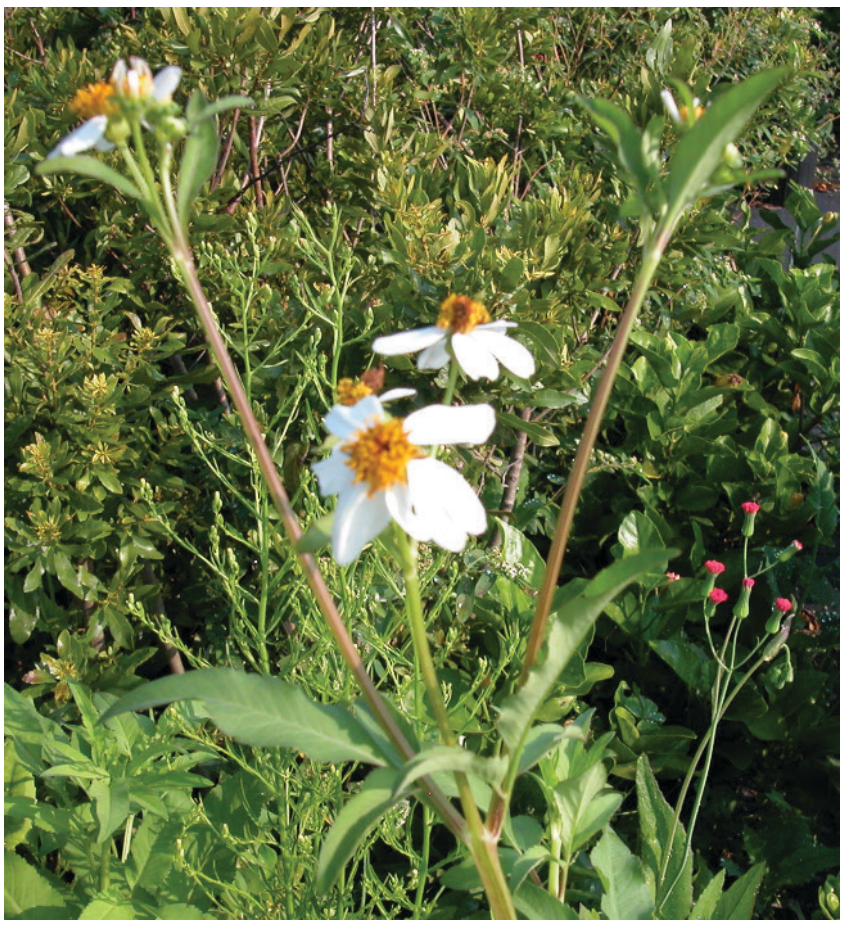

Figure 3. Bidens alba stems.

Credits: Annette Chandler, UF/IFAS

\section{Inflorescence}

B. alba flowers are grouped in terminal heads on the ends of the stems. Each flower head has 4 to 5 long and broad white petals surrounding many tubular yellow disc florets (Figure 5). The flower heads are a quarter-inch across. White or cream-colored petals are usually present but may be absent. B. pilosa usually have disc florets without petals; however, petals may be present. Both species flower year-round in Florida. 


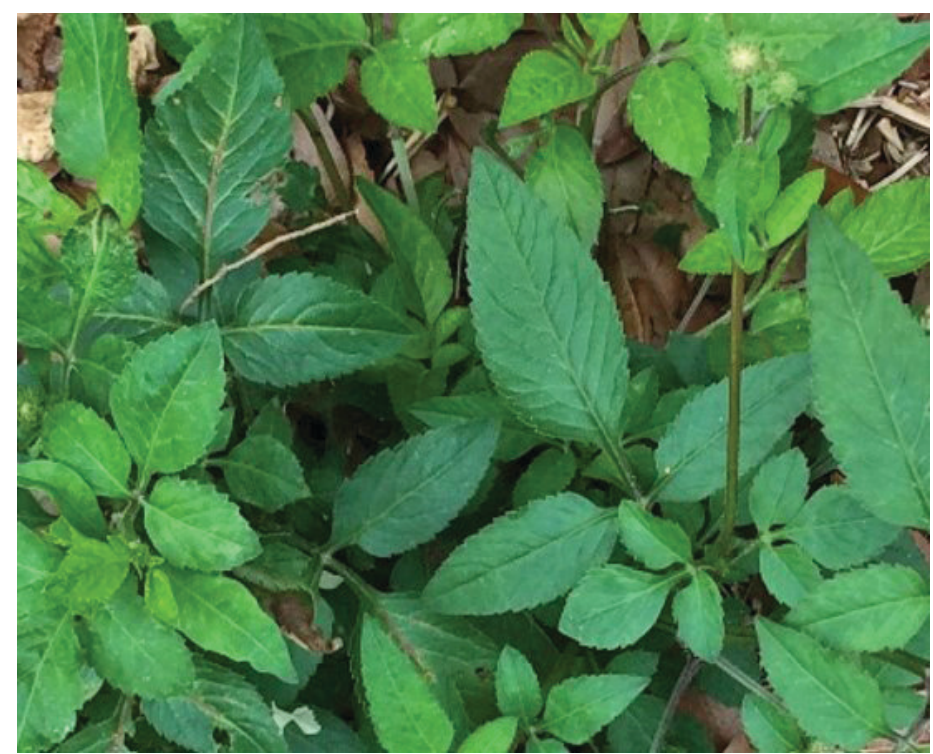

Figure 4. Bidens pilosa leaves.

Credits: Chris Marble, UF/IFAS

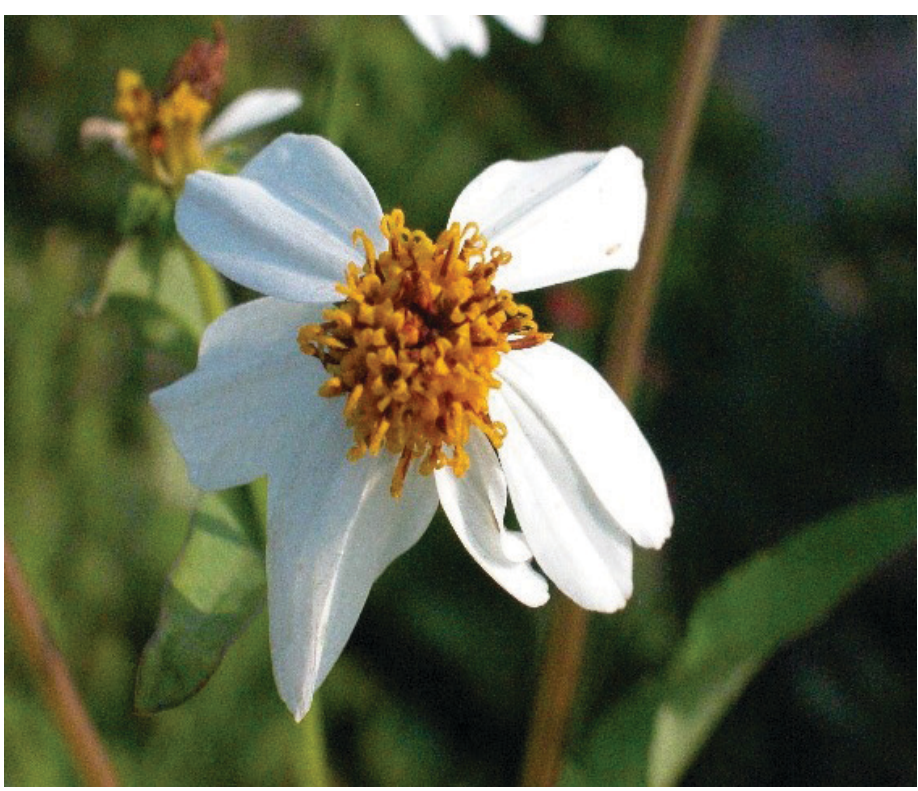

Figure 5. Bidens alba flowers.

Credits: Annette Chandler, UF/IFAS

\section{Fruit and Seeds}

The fruits are dry achenes and contain a single seed, which is black or dark brown in color, linear, and sparsely haired (Figure 8). The hairs consist of a row of 2 to 4 barbed thorns at one end that are up to one-tenth of an inch long. The thorns on the seed aid seed dispersal by attaching to animals, clothing, or machinery.

\section{Similar Species}

The genus Bidens is within the Asteracea family. There are approximately 230 Bidens species with eight species of Bidens found in Florida (Wunderlin et al., 2019). Bidens $a l b a$, also known as beggar-ticks, is closely related to $B$. pilos $a$, and some authors do not differentiate between the two, grouping both species as B. pilosa (Wunderlin, 2019). The Atlas of Florida plants and the USDA Natural Resources Conservation Service recognize both $B$. alba and $B$. pilosa as separate species and classify $B$. alba as a Florida native and $B$. pilosa as an introduced species.

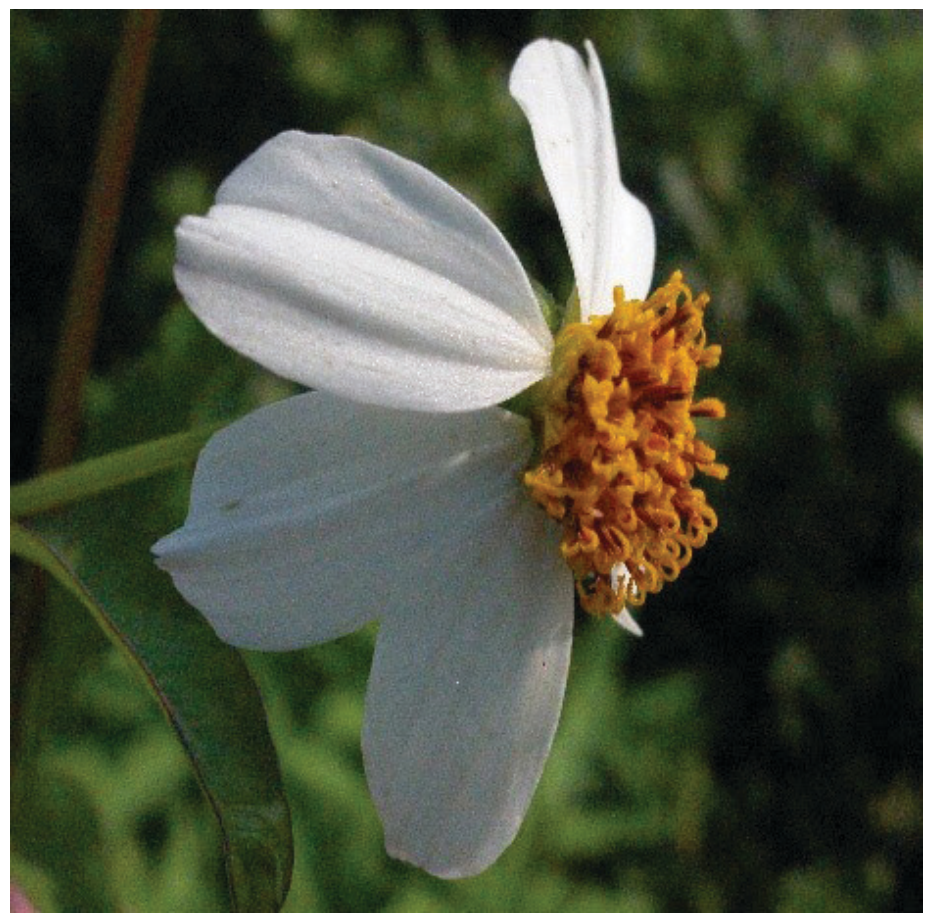

Figure 6. Bidens alba flowers.

Credits: Annette Chandler, UF/IFAS

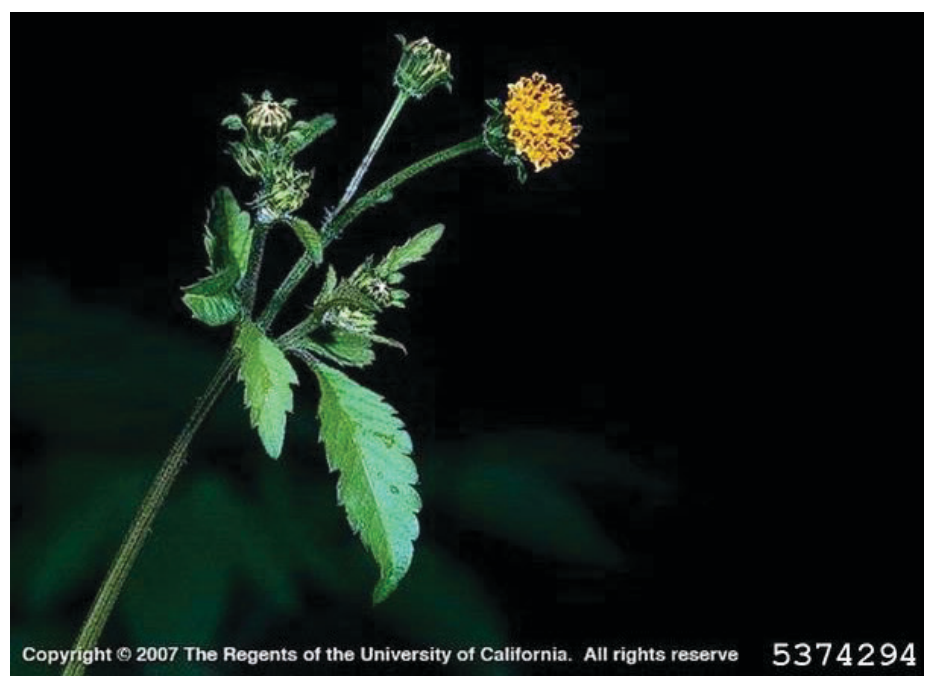

Figure 7. Bidens pilosa flowers.

Credits: Joseph M. DiTomaso, University of California-Davis, Bugwood. org

\section{Plant Biology}

Although Spanish needles are self-pollinating, they still attract pollinators (Guaratini et al., 2004). Seeds germinate on the soil surface or at shallow soil depths. Light and good aeration favor germination, but seeds can also germinate in the dark. They prefer temperatures above $60^{\circ} \mathrm{F}$ but 
are tolerant to frosts, with roots capable of withstanding temperatures as low as $5^{\circ} \mathrm{F}$. One plant can produce between 3,000 and 6,000 highly viable seeds with no dormancy requirement.

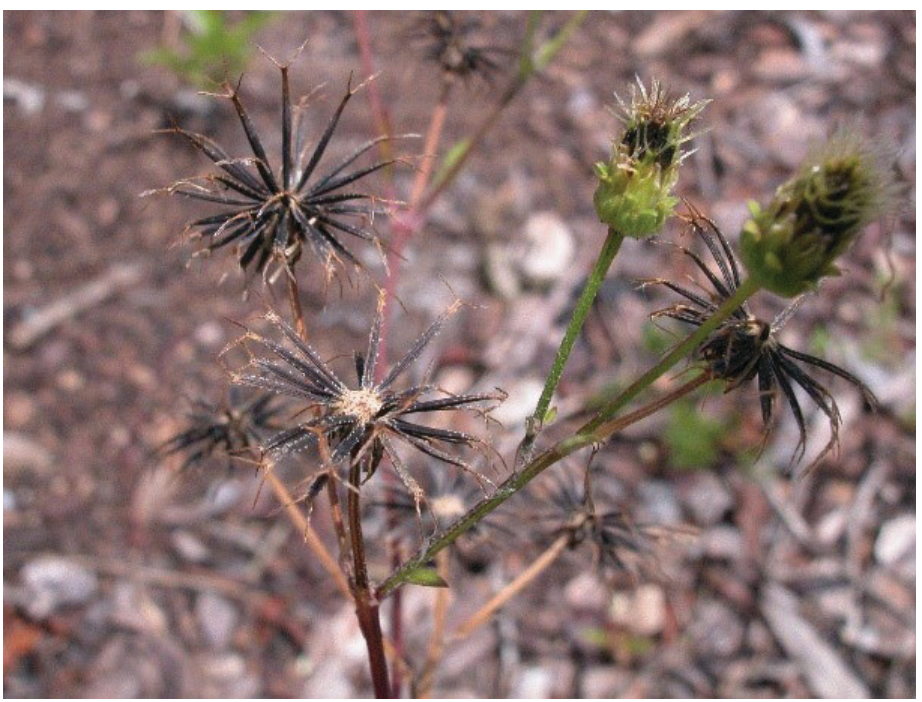

Figure 8. Bidens alba seeds.

Credit: UF/IFAS Annette Chandler

\section{Management Physical and Cultural Control}

Nursery growers can prevent Spanish needles from producing seeds by keeping non-crop areas, walkways, aisles, and other production areas mowed. In containers, it should be hand pulled as soon as possible to prevent seed production. In landscapes, hoeing or tilling can control existing plants where applicable. Thick layers of mulch $(2+$ inches $)$ are likely to reduce germination and growth based on reports from landscape professionals, but no data is currently available on mulch efficacy.

\section{Chemical Control}

The following are recommendations for chemically controlling Spanish needles. However, before applying herbicides of any type, be sure to check the expiration date, wear safety equipment, and thoroughly read the label.

\section{PREEMERGENCE TREATMENTS}

Spanish needles are difficult to manage with preemergence herbicides. In research trials at the University of Florida, 26 different preemergence herbicides or preemergence herbicide combinations were evaluated for control of $B$. alba, with only a spray-applied formulation of Marengo SC (indaziflam) offering satisfactory control ( $75 \%$ reduction in growth). All other preemergence herbicides evaluated provided $\leq 50 \%$ control. The percent control (calculated as a percent reduction in Spanish needle shoot weight in relation to non-treated pots) of each herbicide that was tested is listed in Table 1. In container nurseries, Marengo SC could be used in non-crop areas, roadways, and adjacent to production areas where Spanish needles are a concern. It should be noted that Marengo SC cannot be applied over-the-top of ornamentals. In landscapes, Specticle FLO contains the same active ingredient and is labeled for use as a directed application in landscape beds and in turfgrass. Granular formulations of indaziflam (Marengo $\mathrm{G}$ and Specticle G) are available that can be applied over-the-top of labeled ornamentals, but we have observed less efficacy with these formulations.

\section{POSTEMERGENCE TREATMENTS}

Spanish needles can be controlled postemergence with herbicides such as glyphosate (which has many trade names) and Finale (glufosinate). Glyphosate products vary in concentration of the active ingredient, so labels for the specific glyphosate product that is being used should be followed. We have observed 100\% control of flowering Spanish needles using a broadcast application rate of 2 quarts of product/A ( $2 \mathrm{lbs}$ active ingredient per acre) rate or using a $1.5 \%$ to $2 \%$ glyphosate solution as a spot spray application. Finale is only minimally translocated and thus reduced efficacy may be observed on larger plants. Spot applications of Finale can be applied to control small seedling Spanish needles at rates ranging from 2 to $3 \mathrm{fl}$. oz. per gal. of water. Larger plants may require the high rate (3 fl. oz. per gal.) or multiple applications for satisfactory control. Systemic broadleaf herbicides such as 2,4-D and dicamba have been reported to be effective (Swarbrick, 1997) but these herbicides should not be used in close proximity to ornamentals due to volatility concerns and label restrictions. Resistance to acetolactate synthesis inhibiting herbicides (ALS inhibitors) such as chlorimuron-ethyl and imazethapyr (neither labeled for use in ornamentals) and resistance to glyphosate have been observed with this species (Alcantara-de la Crus et al., 2016; Monquero et al., 2003) in South America and Mexico. However, resistant populations have not been found in Florida. Basagran T/O (bentazon) has also been reported to have efficacy on small seedling Spanish needles, but we have observed poor efficacy once plants begin to flower or exceed 6 inches in height at the highest recommended label rate (32 fl. oz./A). Small Spanish needle plants can also be managed with herbicides such as Reward (diquat) or Scythe (pelargonic acid). Both Reward and Scythe are contact herbicides; thus, thorough coverage is essential, and satisfactory control may not be achieved on larger weeds without making multiple applications. 


\section{References}

Alcantara-de la Cruz, R., P.T. Fernandez-Moreno, C.V. Ozuna, A.M. Rojano-Delgado, H.E. Cruz-Hipolito, J.A. Domingues-Valenzuela, F. Barro, and R. De Prado. 2016. Target and non-target site mechanisms developed by glyphosate-resistant hairy beggarticks (Bidens pilosa L.) populations from Mexico. Front. Plant Sci. https://doi. org/10.3389/fpls.2016.01492.

CAB International (CABI). 2019. CABI invasive species compendium online data sheet. Bidens pilosa (blackjack). CABI Publishing. https://www.cabi.org/ISC.

Guaratini, M.T, V.N Solferini, and J. Semir. 2004. Reproductive biology in species of Bidens L. (Asteraceae). Scientia Agricola. 61:185-189.

Kissmann K and D. Groth. 1993. Plantas infestantes e Nocivas. Sao Paulo, Brazil: BASF Brasileira Tomo II.

Norton R.A. 1991. (Smooth Beggar-Tick) and (Hairy Beggar-Tick). In: Bajaj Y.P.S. (eds) Medicinal and Aromatic Plants III. Biotechnology in Agriculture and Forestry, vol 15. Springer, Berlin, Heidelberg.

Swarbrick, John T. 1997. Weeds of the Pacific Islands. Technical paper no. 209. South Pacific Commission, Noumea, New Caledonia. 124 pp.

USDA-NRCS. 2019. The plants database. National Plant Data Team, Greensboro, NC 27401. https://plants.usda.gov

Wunderlin, R. P., B. F. Hansen, A. R. Franck, and F. B. Essig. 2019. Atlas of Florida Plants. http://florida.plantatlas.usf. edu/. 
Table 1. Preemergence herbicides evaluated for control of Bidens alba (Spanish needles) in Florida.

\begin{tabular}{|c|c|c|c|c|}
\hline Herbicide & Active ingredient(s) & $\begin{array}{l}\text { Spray (S) or Granular } \\
\text { (G) }\end{array}$ & MOA $^{1}$ & Percent Control $^{2}$ \\
\hline Barricade & \multirow[t]{2}{*}{ prodiamine } & $\mathrm{S}$ & 3 & 23 \\
\hline RegalKade & & G & 3 & 9 \\
\hline Pendulum EC & \multirow[t]{2}{*}{ pendimethalin } & $\mathrm{S}$ & 3 & 3 \\
\hline Pendulum G & & G & 3 & 6 \\
\hline Dimension & dithiopyr & $\mathrm{S}$ & 3 & 18 \\
\hline Treflan & trifluralin & G & 3 & 11 \\
\hline Surflan & oryzalin & $\mathrm{S}$ & 3 & 35 \\
\hline Ronstar & oxadiazon & G & 14 & 7 \\
\hline SureGuard & \multirow[t]{2}{*}{ flumioxazin } & $\mathrm{S}$ & 14 & 15 \\
\hline Broadstar & & G & 14 & 11 \\
\hline Biathlon & oxyfluorfen + prodiamine & G & $14+3$ & 10 \\
\hline $\mathrm{OH} 2$ & oxyfluorfen + pendimethalin & G & $14+3$ & 6 \\
\hline Rout & oxyfluorfen + oryzalin & G & $14+3$ & 7 \\
\hline Pennant Magnum & S-metolachlor & $\mathrm{S}$ & 15 & 12 \\
\hline Tower & dimethenamid-P & $\mathrm{S}$ & 15 & 10 \\
\hline Tower + Pendulum EC & \multirow[t]{2}{*}{ dimethenamid-P + pendimethalin } & $\mathrm{S}$ & $15+3$ & 6 \\
\hline FreeHand & & G & $15+3$ & 12 \\
\hline Gallery & isoxaben & $\mathrm{S}$ & 21 & 28 \\
\hline Snapshot & isoxaben + trifluralin & G & $3+21$ & 18 \\
\hline Gallery + Barricade & \multirow[t]{3}{*}{ isoxaben + prodiamine } & $\mathrm{S}$ & $3+21$ & 30 \\
\hline Gemini SC & & $\mathrm{S}$ & $3+21$ & 2 \\
\hline Gemini G & & G & $3+21$ & 26 \\
\hline Gallery + Dimension & \multirow[t]{2}{*}{ isoxaben + dithiopyr } & $\mathrm{S}$ & $3+21$ & 16 \\
\hline Fortress & & G & $3+21$ & 22 \\
\hline Marengo SC & \multirow[t]{2}{*}{ indaziflam } & $S$ & 29 & 73 \\
\hline Marengo G & & G & 29 & 47 \\
\hline \multicolumn{5}{|c|}{$\begin{array}{l}{ }^{1} \text { Herbicide groups are based according to primary sites of action and can be used to select herbicides that have differing sites of action (Weed } \\
\text { Technology 17:605-619 [2003]) to minimize the potential for the development of herbicide-resistant weeds. } \\
{ }^{2} \text { Percent control is based on percent reduction in weed biomass in relation to the non-treated control. } 100 \%=100 \% \text { reduction in biomass } \\
\text { or total control, } 0=0 \% \text { reduction in biomass or no control. Percent control shows averages over two separate trials in } 2017 \text { and } 2018 \text { using } 8 \\
\text { replications per treatment, per trial. All herbicides were evaluated at their highest recommended label rate, with the exception of Marengo SC } \\
\text { which was evaluated at } 9 \text { fl. oz. per acre. }\end{array}$} \\
\hline
\end{tabular}

